\title{
Sorghum Yield Response to Changing Climatic Conditions in Semi-Arid Central Tanzania: Evaluating Crop Simulation Model Applicability
}

\author{
Barnabas Msongaleli1 ${ }^{*}$, Filbert Rwehumbiza², Siza D. Tumbo³, Nganga Kihupi ${ }^{3}$ \\ ${ }^{1}$ Department of Geography and Environmental Studies, University of Dodoma, Dodoma, Tanzania \\ ${ }^{2}$ Department of Soil Science, Sokoine University of Agriculture, Morogoro, Tanzania \\ ${ }^{3}$ Department of Agricultural Engineering and Land Planning, Sokoine University of Agriculture, Morogoro, \\ Tanzania \\ Email: ${ }^{\text {bmsongaleli@yahoo.co.uk }}$
}

Received 7 June 2014; revised 9 July 2014; accepted 1 August 2014

Copyright (C) 2014 by authors and Scientific Research Publishing Inc.

This work is licensed under the Creative Commons Attribution International License (CC BY). http://creativecommons.org/licenses/by/4.0/

(c) (i) 0 pen Access

\section{Abstract}

Decision Support System for Agrotechnology Transfer (DSSAT) and Agricultural Production Systems SIMulator (APSIM) were calibrated and evaluated to simulate sorghum (Sorghum Bicolor L. Moench) var. Tegemeo under current and future climate in central Tanzania. Simulations for both current and future periods were run assuming present technology, current varieties and current agronomy packages to investigate rain-fed sorghum yield response. Simulations by both crop models using downscaled weather data from eight General Circulation Models (GCMs) under the Coupled Model Intercomparison Project phase 5 (CMIP5) and Representative Concentration Pathway (RCP 4.5) by mid-century show a mixture of increase and decrease in median sorghum yields. Four GCMs project yields to increase by $5 \%-23.0 \%$ and one GCM show a decrease by $2 \%-9 \%$. Model simulations under the remaining three GCMs give contrasting results of increase and decrease. Adjustment of crop duration to mimic the choice of growing local cultivars versus improved cultivars seems a feasible option under future climate scenarios. Our simulation results show that current open-pollinated sorghum cultivars would be resilient to projected changes in climate by 2050 s but things seem better with long duration cultivars. We conclude that crop simulation models show their applicability as tools for assessing possible impacts of climate change on sorghum due to agreement in the direction of crop yield predictions in five out of eight selected GCMs under projected climate scenarios. The findings provide useful guidance and motivation to government authorities and development agencies dealing with food security issues to prioritize adaptations policies geared to ensuring increased and sustained sorghum productivity

${ }^{*}$ Corresponding author.

How to cite this paper: Msongaleli, B., Rwehumbiza, F., Tumbo, S.D. and Kihupi, N. (2014) Sorghum Yield Response to Changing Climatic Conditions in Semi-Arid Central Tanzania: Evaluating Crop Simulation Model Applicability. Agricultural Sciences, 5, 822-833. http://dx.doi.org/10.4236/as.2014.510087 


\title{
in Tanzania and elsewhere.
}

\section{Keywords}

\author{
Yield Prediction, Climate Change, Adaptation, Model Evaluation
}

\section{Introduction}

Sorghum is one of the grain crops grown under predominantly rain-fed conditions but it is the main staple for the food insecure people in Eastern and Central Africa (ECA), and accounts for $41 \%$ of the region's grain production [1]. Despite the development and release of improved high yielding sorghum varieties with short growth cycles favorable for the semi-arid areas including central Tanzania [2], weather and climate remain key factors in sorghum productivity. Indeed, there is compelling evidence that climate variability and change will affect crop yields, though significant uncertainty surrounds the prediction of cereal yields under projected changes in climate especially for dry-land/rain-fed regions [3]. Production of rain-fed grain crops is projected to be negatively affected through projected higher and more variable temperatures, changes in rainfall patterns and increased occurrences of extreme events such as droughts and floods [4]. Attaining objectives of increasing and sustaining future grain yield requires a good understanding of the response of crops and a reliable crop yield prediction under different projected climate scenarios. Although existing crop simulation models are not capable of capturing and quantifying the effects of weather extremes, they are still appropriate tools in the quest to understand the climate change impacts on crops and in devising plausible crop adaptation strategies [5] [6].

Agricultural Production Systems SIMulator (APSIM) [7] [8] and Decision Support Systems for Agrotechnology Transfer (DSSAT) [9] [10] are crop simulation models widely used at present. APSIM is a modular modeling framework developed in Australia. It runs at a daily time step and simulates crop growth and development, yield, soil water and nitrogen dynamics either for single crop or crop rotations in response to climatic and management changes. According to Keating [8] APSIM has been tested in a diverse range of systems and environments, including model performance in long-term cropping systems. Similarly, DSSAT is operated on a daily time step and takes into account the effects of cultivar, crop management, weather, soil moisture and nutrition. Jones [9] reviewed the intensive testing and wide application of DSSAT model over 15 years. In a recent study, Wang [11] demonstrate the applicability of CERES-Maize model embedded in DSSAT to assess the vulnerability to climate change, analyze the potential adaptation options both in crop management and cultivar changes in maize in China.

Several studies demonstrate the importance of combining general circulation models (GCMs), emissions scenarios, and crop simulation models to explore the possible range of climate change impacts on cereal crops in the semi-arid tropics with and without adaptation e.g. [12]-[14]. However, all these studies indicate strong contrasting conclusions regarding yield variability, some projecting crop yield increase, some showing decrease while others show no change from baseline. The underlying uncertainty in projections seem to limit the scope of confidence in identifying potential adaptation options for smallholder farmers who have been living with illfates of the negative impacts from the vagaries of weather, and in most cases ignoring the existence of potential positive impacts such as those resulting from increased rainfall.

Assessment of the likely impacts of climate variability and future change in climate on agriculture in Tanzania indicated that some of the previous highly productive areas such as the southern and northern highlands will be affected by declining rainfall, frequent droughts and significant increase in spatial and temporal variability of rainfall [15]. In an earlier study, Mwandosya [16] indicated that maize average yield in Tanzania is expected to decrease by $33 \%$ under $2 \times \mathrm{CO}_{2}$ (doubling of greenhouse gases) scenario by end of century, which is expected to increase temperature to between $2.5^{\circ} \mathrm{C}$ and $4^{\circ} \mathrm{C}$. These results point to the fact that crop production is predicted to decline substantially for maize, the main staple crop for the country, but also that we should be wary of possible negative implications for the drought tolerant crops such as sorghum and millet. In their modelling study, IFPRI [17] indicate that at sub-Saharan scale overall sorghum and millet yields are projected to be slightly higher under climate change, probably given their higher tolerance to higher temperatures and drought stress. However, the projections by IFPRI are based on the assumption that all cereals including sorghum and millets which follow the C4 pathway would behave similar to the generic maize variety (Garst 8808). For more reliable 
simulation results some studies contend that crop models used to study impacts and adaptation options, should imperatively use locally available cultivars in models rather than generic cultivars [18]. This is particularly true for crops such as sorghum, millet, upland rice and tropical legumes where diverse, usually photoperiod-sensitive cultivars are grown.

Because there is scanty information in Tanzania regarding the yield projections of existing improved sorghum cultivars towards new climatic futures, the present study strives to fill this gap. It examines the effect of medium term climate variability and the change on sorghum production in central Tanzania and identifies the adaptation options using simulation modelling. The first objective was to calibrate and evaluate Agricultural Production Systems SIMulator (APSIM) and Decision Support System for Agrotechnology Transfer (DSSAT) crop simulation models. The second objective was to simulate the impacts of future climate change scenarios on sorghum productivity. The third objective was to evaluate one adaptation option namely cultivar selection, improved versus local.

\section{Materials and Methods}

\subsection{Description of the Study Area}

Field experiment was conducted at Hombolo agricultural research institute (ARI) in Dodoma, central region of Tanzania. The site is located about $58 \mathrm{~km}$ North-East of Dodoma Municipality at $05^{\circ} 45^{\prime} \mathrm{S}$ latitude, $35^{\circ} 57^{\prime} \mathrm{E}$ longitude. The average annual rainfall is $589 \mathrm{~mm}$ but the distribution is highly variable with high intensities. The site is located in the zone which is one of the most sensitive to climate variability and change, but it account for three-quarters of Tanzania's 500,000 to 800,000 tons of annual sorghum harvest. The average annual temperature is $22.7^{\circ} \mathrm{C}$. Summary of temperature and rainfall records during the growing season are shown in Table 1 .

\subsection{Cultivar}

Cultivar Tegemeo which is an open pollinated variety was chosen due to existence of data from previous experiments. Moreover, it is stable and widely used in Tanzania by several small-scale farmers since its release in 1978 [19]. Therefore, simulating the effects of climate variability and change on the cultivar would provide insights into possible impact of climate change on sorghum yield in the future.

\subsection{Models Description and Parameterization}

CERES (Crop-Environment-Resource-Synthesis)-sorghum module [20] within the DSSAT version 4.5 and APSIM were used in the present study. APSIM (version 7.4) modules used were Sorghum, SoilWat (soil water balance) and MANURE. Crop development is controlled by temperature (thermal degree days) and photoperiod. For both models, thermal time accumulations were derived using algorithm described in [21] using observed phenology and weather data, a base temperature of $8^{\circ} \mathrm{C}$ and an optimal temperature of $30^{\circ} \mathrm{C}$. Daily weather data during the growing season were obtained from observations at an agro-met station, which is about $500 \mathrm{~m}$ from the experimental plots. These include minimum and maximum temperatures, rainfall and sunshine hours which in turn are used to estimate solar radiation.

Table 1. Mean monthly weather characteristics from December 2012 to June 2013.

\begin{tabular}{|c|c|c|c|}
\hline December & 31.3 & 20.1 & 56.1 \\
\hline February & 31.8 & 20.0 & 33.1 \\
\hline April & 30.1 & 19.4 & 72.5 \\
\hline May & 29.2 & 17.8 & 9.3 \\
\hline June & 28.3 & 15.7 & 0 \\
\hline
\end{tabular}




\subsection{Field Experiment for Model Calibration}

Data from an experiment carried out between Jan-May 2013 at Hombolo Agricultural Research Station were used to parameterize the models. Planting was done on 4th January 2013 with a spacing of $75 \times 30 \mathrm{~cm}$ and arranged in a randomized complete block design (RCBD). In order to provide near-optimum conditions, Diammonium phosphate (DAP) fertilizer was applied during planting to supply $40 \mathrm{~kg} / \mathrm{N}$ per ha, and four to five seeds were sown. Another round of $\mathrm{N}$ fertilization was done by applying $40 \mathrm{Kg} \mathrm{N} / \mathrm{ha}$ as urea seven weeks after planting. Supplemental irrigation was done and other standard agronomic practices were followed. Phenological data including date of flowering, date for start of grain filling and date of physiological maturity were collected. These were noted when $50 \%$ of plant population per plot attained each of these stages. Start of grain filling was determined by observing the presence of milky substance in grain at the base of the panicles. Physiological maturity is attained when dark layer forms at the point of attachment of the grain to the panicle. At final harvest, total above-ground biomass and yield were determined. Grain yield was determined by harvesting panicles from an area $9 \mathrm{~m}^{2}$ and grains separated from it. Sub-samples with known weight were dried at $70^{\circ} \mathrm{C}$ to a constant weight. Dried weight of sub-samples are used to determine dry weight from the harvested area and then expressed as $t \cdot h a^{-1}$. Above-ground biomass at maturity was harvested by cutting plants just above the surface of the ground and fresh weight noted. Sub-samples with known fresh weight were taken for each replicate and dried to a constant weight at $70^{\circ} \mathrm{C}$. Above-ground biomass per hectare was then determined as in the case of grain yield. Models calibration was done by iteratively adjusting the parameters to obtain as close as possible the simulated and observed values of phenology (i.e. anthesis and maturity dates) and grain and biomass yields as described by [10].

Soils at the site are mainly sandy and loamy of low fertility and seasonally waterlogged or flooded clays. They are classified as ferralic Cambisols in the FAO classification. Soil-related modules were parameterized mainly with measured data from experiments carried out under optimal growth conditions, and from related literature. Disturbed and undisturbed soil samples which were taken in soil profiles $(0$ - 15, 15 - 30, 30 - 45, 45 60, 60 - 75 and $75-105 \mathrm{~cm}$ ) prior to sowing were analyzed for organic carbon (OC \%), $\mathrm{pH}$, and particle size distribution as described in [22]. Input data related to soil characteristics include soil texture, number of layers in soil profile, soil layer depth, $\mathrm{pH}$ of soil for each depth, clay, silt and sand contents, organic matter, cation exchange capacity, etc. The soil profile data used in the parameterization of the models is presented in Table 2.

\subsection{Field Experiment for Model Evaluation}

In order to evaluate both crop models to simulate sorghum, data from a previous experiment namely "tillage cum fertilizer application" [23] with variety Tegemeo were used. The experiment was conducted at the same location i.e. Hombolo Agricultural Research Station under rainfed conditions with several treatments. The treatment which gave high sorghum grain yields was purposely selected to include in the model evaluations i.e. Farm Yard Manure application at $10 \mathrm{t} / \mathrm{ha}$ plus mulch and Triple Superphosphate applied at $100 \mathrm{~kg} / \mathrm{ha}$ and Nitrogen fertilizer applied at $40 \mathrm{~kg}-\mathrm{N} / \mathrm{ha}$. The study collected data on phenology, biomass and grain yields pertaining to the selected treatment. The calibrated model was evaluated by comparing observed values for grain yield and total above-ground biomass with those from model simulations. Model performance was assessed through root

Table 2. Soil analytical data for a soil profile at Hombolo.

\begin{tabular}{|c|c|c|c|c|c|c|c|c|c|}
\hline $\begin{array}{l}\text { Depth of } \\
\text { bottom }\end{array}$ & $\begin{array}{l}\text { Clay } \\
\%\end{array}$ & $\begin{array}{c}\text { Silt } \\
\%\end{array}$ & $\begin{array}{l}\text { Organic } \\
\text { carbon \% }\end{array}$ & $\begin{array}{l}\mathrm{pH} \text { in } \\
\text { water }\end{array}$ & $\begin{array}{l}\text { Cation exchange } \\
\text { capacity }(\mathrm{cmol} / \mathrm{kg})\end{array}$ & $\begin{array}{c}\text { Total } \\
\text { nitrogen (\%) }\end{array}$ & $\begin{array}{l}\text { Lower limit } \\
(\mathrm{LL}) \mathrm{cm}_{3} / \mathrm{cm}_{3}\end{array}$ & $\begin{array}{l}\text { Drained upper limit } \\
\text { (DUL) } \mathrm{cm}_{3} / \mathrm{cm}_{3}\end{array}$ & $\begin{array}{c}\text { Saturation } \\
(\mathrm{SAT}) \mathrm{cm}_{3} / \mathrm{cm}_{3}\end{array}$ \\
\hline 15 & 19 & 5 & 0.41 & 4.8 & 6.0 & 0.07 & 0.122 & 0.188 & 0.375 \\
\hline 30 & 20 & 4 & 0.31 & 4.6 & 8.2 & 0.06 & 0.121 & 0.181 & 0.366 \\
\hline 45 & 23 & 4 & 0.23 & 4.5 & 9.2 & 0.12 & 0.145 & 0.206 & 0.366 \\
\hline 60 & 25 & 5 & 0.14 & 4.5 & 10.2 & 0.05 & 0.145 & 0.205 & 0.361 \\
\hline 75 & 34 & 2 & 0.14 & 4.6 & 10.0 & 0.05 & 0.190 & 0.249 & 0.364 \\
\hline 105 & 30 & 4 & 0.06 & 4.6 & 6.0 & 0.04 & 0.166 & 0.227 & 0.367 \\
\hline
\end{tabular}


mean square error (RMSE) Equation (1). [24].

$$
R M S E=\sqrt{\frac{1}{N}} \sum(\hat{Y i}-Y i)^{2}
$$

and index of agreement or d-statistic, Equation (2) [25],

$$
d=1-\left[\frac{\sum_{i=1}^{n}(\hat{Y} i-Y i)(\hat{Y} i-Y i)}{\sum_{i=1}^{n}(|\hat{Y} i-\bar{Y} i|+|Y i-\overline{Y i}|)}\right]
$$

where $\hat{Y}, Y$ and $\bar{Y}$ are respectively, the simulated, observed and mean of the observed values and $\mathrm{n}$ is the number of observations. For good agreement between model simulations and observations, $d$-statistic should approach unity.

\subsection{Impact Assessment Methodology}

A simple delta method was used to create climate change scenarios for mid-century (2040-2070) for 8 AOGCMS (Coupled atmosphere-ocean general circulation models) from Coupled Model Intercomparison Project phase 5(CMIP5) and Representative Concentration Pathway (RCP 4.5). The assumption in the delta method is that future model biases for both mean and variability are the same as those in present day simulations [26]. The approach used a combination of the Commonwealth Scientific and Industrial Research Organization mark 3.0 (CSIRO-MK3.0), Community Climate System Model (CCSM4), BCC-CSM1-1, BNU-ESM, Canadian Earth System Model (CanESM2), IPSL-CM5A-LR, IPSL-CM5A-MR and MIROC5 GCMs scenarios under CMIP5 and observed (1980-2010) (baseline). In order to capture the ordinary smallholder farmers' management practices the plant population was set at 6 plants per square meter with the row spacing of $90 \mathrm{~cm}$ and a low dosage of nitrogen set at $20 \mathrm{~kg} \mathrm{~N}$ per ha. The simulations were made using a fixed concentration of atmospheric $\left[\mathrm{CO}_{2}\right]$ of $390 \mathrm{ppm}$ for the baseline (the value reported for the year 2010 in the fourth assessment report of IPCC) and $\left[\mathrm{CO}_{2}\right]$ of $499 \mathrm{ppm}$ for the mid-century (the value given for RCP4.5 midcentury AgMIP climate scenario). To express the impacts on yield, the simulation results on grain yield were compiled and relative yield deviations from baseline yields were calculated. The eight GCMs were chosen based on their use in previous studies in the region and their better representation of projected climate, in terms of temperature and rainfall patterns in Eastern Africa [15] [27].

\subsection{Testing Adaptation Option}

Using calibrated models and parameters, one treatment was evaluated in order to identify its feasibility as an adaptation option. Mimicking late-maturing local cultivars was undertaken by creating hypothetical cultivars. This was made possible through adjusting the genetic coefficients of "Tegemeo" in such a way that they would prolong the vegetative period under climate change conditions. According to [28] genetic coefficients can be modified for long term simulation to incorporate the advancements expected in the breeding program.

\section{Results and Discussion}

\subsection{Model Calibration and Performance}

Results of model calibrations and the derived parameters are presented in Table 3 and Table 4 for DSSAT and APSIM, respectively.

As shown in Table 5, simulated days to anthesis, days to physiological maturity and grain yield closely matched with their observed values. Statistical indicators of model performance are shown in Table 6. As shown in Table 6, root mean square error (RMSE) values are low, since they compare the agreement of simulated versus observed values, thus the lower the values of RMSE the better the model in explaining most of the variations in the dataset. Moreover, data indicate that the simulated grain yield values reasonably matched observed values, owing to the agreement index (d-statistic) of 0.5 for both models. However, the variation in biomass simulations constitute some error level as indicated by very low values of d-statistic in both models. The dstatistic values close to 1 are regarded as better simulations and according to these statistical indicators, APSIM especially seems to over predict biomass. Varshneya [29] indicate CERES-sorghum model's ability to accu- 
Table 3. Cultivar coefficient testing for CERES-Sorghum after calibration and evaluation of Tegemeo.

\begin{tabular}{|c|c|c|c|c|c|}
\hline Coefficient & \multicolumn{4}{|c|}{ Definition } & Setting \\
\hline TBASE & \multicolumn{4}{|c|}{ Base temperature below which no development occurs ${ }^{\circ} \mathrm{C}$} & 8.0 \\
\hline TOPT & \multicolumn{4}{|c|}{ Temperature at which maximum development rate occurs during vegetative stages ${ }^{\circ} \mathrm{C}$} & 34.0 \\
\hline ROPT & \multicolumn{4}{|c|}{ Temperature at which maximum development rate occurs for reproductive stages ${ }^{\circ} \mathrm{C}$} & 34.0 \\
\hline RUE & \multicolumn{4}{|c|}{ Radiation use efficiency, g plant dry matter MJ PAR ${ }^{-1}$} & 4.0 \\
\hline KCAN & \multicolumn{4}{|c|}{ Canopy light extinction coefficient for daily PAR } & 0.85 \\
\hline $\mathrm{P} 1$ & \multicolumn{4}{|c|}{$\begin{array}{l}\text { Thermal time from seedling emergence to the end of the juvenile phase (expressed in degree days } \\
\text { above a base temperature of } 8^{\circ} \mathrm{C} \text { ) during which the plant is not responsive to changes in photoperiod. }\end{array}$} & 430 \\
\hline $\mathrm{P} 2 \mathrm{O}$ & \multicolumn{4}{|c|}{$\begin{array}{l}\text { Critical photoperiod or the longest day length (in hours) at which development occurs at a maximum rate. } \\
\text { At values higher than P20, the rate of development is reduced. }\end{array}$} & 12.50 \\
\hline $\mathrm{P} 2 \mathrm{R}$ & \multicolumn{4}{|c|}{$\begin{array}{l}\text { Extent to which phasic development leading to panicle initiation (expressed in degree days) } \\
\text { is delayed for each hour increase in photoperiod above P20. }\end{array}$} & 1.0 \\
\hline P5 & \multicolumn{4}{|c|}{$\begin{array}{l}\text { Thermal time (degree days above a base temperature of } 8^{\circ} \mathrm{C} \text { ) from beginning of grain filling } \\
\text { ( } 3 \text { - } 4 \text { days after flowering) to physiological maturity. }\end{array}$} & 600.0 \\
\hline G1 & \multicolumn{4}{|c|}{ Scaler for relative leaf size. } & 5.0 \\
\hline G2 & \multicolumn{4}{|c|}{ Scaler for partitioning of assimilates to the panicle (head). } & 6.5 \\
\hline PHINT & \multicolumn{4}{|c|}{ Phylochron interval; the interval in thermal time (degree days) between successive leaf tip appearances. } & 49.00 \\
\hline \multicolumn{2}{|r|}{ Parameter } & Source & Units & Value & \\
\hline \multicolumn{6}{|c|}{ Thermal time accumulation } \\
\hline \multicolumn{2}{|r|}{ Duration-end of juvenile to panicle initiation } & $\mathrm{C}$ & ${ }^{\circ} \mathrm{C}$ day & 245 & \\
\hline \multicolumn{2}{|r|}{ Duration-flag leaf to flowering stage } & $\mathrm{C}$ & ${ }^{\circ} \mathrm{C}$ day & 195 & \\
\hline \multicolumn{2}{|r|}{ Duration-flowering to start of grain filling } & $\mathrm{C}$ & ${ }^{\circ} \mathrm{C}$ day & 80 & \\
\hline \multicolumn{2}{|r|}{ Duration-flowering to maturity } & $\mathrm{C}$ & ${ }^{\circ} \mathrm{C}$ day & 760 & \\
\hline \multicolumn{2}{|r|}{ Duration-maturity to seed ripening } & $\mathrm{L}$ & ${ }^{\circ} \mathrm{C}$ day & 1 & \\
\hline \multicolumn{6}{|c|}{ Photoperiod } \\
\hline \multicolumn{2}{|r|}{ Daylength photoperiod to inhibit flowering } & $\mathrm{D}$ & $\mathrm{H}$ & 11.5 & \\
\hline \multicolumn{2}{|r|}{ Daylength photoperiod for insensitivity } & $\mathrm{D}$ & $\mathrm{H}$ & 13.5 & \\
\hline \multicolumn{2}{|r|}{ Photoperiod slope } & $\mathrm{L}$ & ${ }^{\circ} \mathrm{C} / \mathrm{h}$ & 0.01 & \\
\hline \multicolumn{2}{|r|}{ Soil water stress factor } & $\mathrm{D}$ & - & 1.125 & \\
\hline \multicolumn{2}{|r|}{ Plant height (max) } & $\mathrm{O}$ & $\mathrm{mm}$ & 1650 & \\
\hline \multicolumn{2}{|r|}{ Base temperature } & $\mathrm{L}$ & ${ }^{\circ} \mathrm{C}$ day & 8 & \\
\hline \multicolumn{2}{|r|}{ Optimum temperature } & $\mathrm{D}$ & ${ }^{\circ} \mathrm{C}$ day & 30 & \\
\hline
\end{tabular}

$\mathrm{C}$ = calibrated; $\mathrm{D}$ = default; $\mathrm{L}$ = literature; $\mathrm{O}=$ observed.

Table 5. Comparison of observed and simulated parameters after model evaluation.

\begin{tabular}{|c|c|c|c|c|c|c|}
\hline & \multicolumn{3}{|c|}{ Calibration experiment } & \multicolumn{3}{|c|}{ Evaluation experiment } \\
\hline & \multirow[t]{2}{*}{ Observed $^{\ddagger}$} & \multicolumn{2}{|c|}{ Simulated } & \multirow[t]{2}{*}{ Observed } & \multicolumn{2}{|c|}{ Simulated } \\
\hline & & DSSAT & APSIM & & DSSAT & APSIM \\
\hline Anthesis days & 73 & 72 & 71 & 73 & 72 & 71 \\
\hline Maturity days & 114 & 115 & 114 & 114 & 115 & 114 \\
\hline Grain yield $\left(\mathrm{kg} \cdot \mathrm{ha}^{-1}\right)$ & $3789(68.1)$ & 4111 & 4105 & $2657(92.3)$ & 3030 & 3235 \\
\hline Above-ground biomass $\left(\mathrm{kg} \cdot \mathrm{ha}^{-1}\right)$ & 10334 (167.3) & 10,947 & 11,310 & $9213(172.5)$ & 9321 & 9801 \\
\hline
\end{tabular}

\footnotetext{
${ }^{\ddagger}$ Observed values are the averages of three replications with their standard deviations in parentheses.
} 
Table 6. Statistical indicators of model performance.

\begin{tabular}{ccccc}
\hline Crop parameters & DSSAT & APSIM & d-statistic \\
& RMSE & d-statistic & RMSE & 0.50 \\
Grain yield & 348 & 0.50 & 428 & 987 \\
Biomass & 359 & 0.29 & 0.47 \\
\hline
\end{tabular}

rately predict phenology and biomass yields under normal sowing conditions, populations, and with adequate moisture under rainfed conditions in India. But they noted that biomass varied significantly under conditions of water stress and kernel weight was underestimated due to the model's inability to account for changes in panicle size under receding soil moisture conditions. Moreover, [30] showed that the model simulated improper tillering response to changes in plant density, thus some variations in biomass as observed in the present study are likely.

\subsection{Historical and Future Climatic Trends}

Analyses of annual and seasonal maximum and minimum temperatures and rainfall at Hombolo station by mid-century as compared to baseline period are shown in Figure 1. All GCMs indicate rise in maximum temperature by between $2.7^{\circ} \mathrm{C}$ and $4.0^{\circ} \mathrm{C}$. The temperature projections by the eight GCMs are, however in disagreement with the projections of IPCC which show increases of about $1{ }^{\circ} \mathrm{C}-2^{\circ} \mathrm{C}$ to the 2050 s and about $1.5^{\circ} \mathrm{C}$ $3^{\circ} \mathrm{C}$ for the 2080s [31] in Eastern Africa. The reasons for the disagreement may be due to the scale at which IPCC projections are made vis-a-vis the downscaling procedures used in generating the data used in these analyses. Moreover, rainfall projections for annual and the months of January, February and March (JFM) rainfall show diverse results with increase as well as decrease under different GCMs. The JFM are important in the study area because during the growing season, they span the period from juvenile stages to start of grain filling for sorghum. Results indicate that CANES and IPSL-CM5A-LR are the only GCMs which show that there will be increase in both annual and seasonal rainfall. CSIRO-Mk3 shows the highest decline in JFM rainfall followed by MIROC5, BCC-CSM1, BNU-ESM and IPSL-CM5A-MR. The highest projected annual rainfall decline is shown in MIROC5 followed by CSIRO-Mk3, BCC-CSM1 BNU-ESM and CCSM4. Moore [14] on the contrary, report an increase of 50 to $100 \mathrm{~m}$ of mean annual rainfall throughout central Tanzania from 2000-2050 under the SRES A1B scenario climate change projection of CCSM4.

\subsection{Projections of Sorghum Yields}

Simulation results under different GCMs by 2050s under RCP 4.5 are shown in Figure 2. The simulated grain yields under baseline (1.0 - $1.1 \mathrm{t} / \mathrm{ha}$ ) give realistic estimates of the current grain yields obtained by farmers under normal management practices. The change in sorghum yields under both APSIM and DSSAT reveal consistency only with the four GCMs (CSIRO-MK3.0, IPSL-CM5A-LR, IPSL-CM5A-MR and MIROC5) where a 5\% - 23\% increase in median sorghum yields is predicted. For the three GCMs the two crop models give contrasting results, with the exception of CANESM2 where they both agree that there will be a $2 \%$ - $5 \%$ decline in sorghum yields in the future compared to baseline. For the four GCMs which indicate yield increase, the results are in agreement with IPCCs projections that, change from present to 2080-2099 indicate an 20\% - 48\% increase in sorghum yields in East Africa under projected temperature increase of $3.2^{\circ} \mathrm{C}$ and rainfall increase of $7 \%$ [32]. However, increase in rainfall amounts projected by GCMs does not match with the increase in simulated grain yields (e.g. CANESM2) (Figure 1) in that while an increase in both annual and seasonal rainfall is shown the simulated grain yields are low. A previous study by [33] similarly observed that it is the temporal distribution of rainfall during the cropping season rather than the total amount which determines the productivity and yield of sorghum in the particular season. On the other hand, the relative role of temperature and rainfall in projections of crop yields create a plausible divergence in that the two variables are closely linked and interact and depend on scale and geographical location. For instance, [3] observe that yield changes in arid zones appear to be mainly driven by rainfall changes; in contrast, yield appears proportional to temperature in equatorial and temperate zones. According to [34] significant reduction in sorghum yields would occur when temperatures rise by $4^{\circ} \mathrm{C}$ to $7^{\circ} \mathrm{C}$ above optimum $\left(32 / 22^{\circ} \mathrm{C}\right)$ in combination with appreciable reduction in rainfall is attained. Results from the current study are in agreement with previous studies e.g. [35] [36] which show that sorghum yields are 


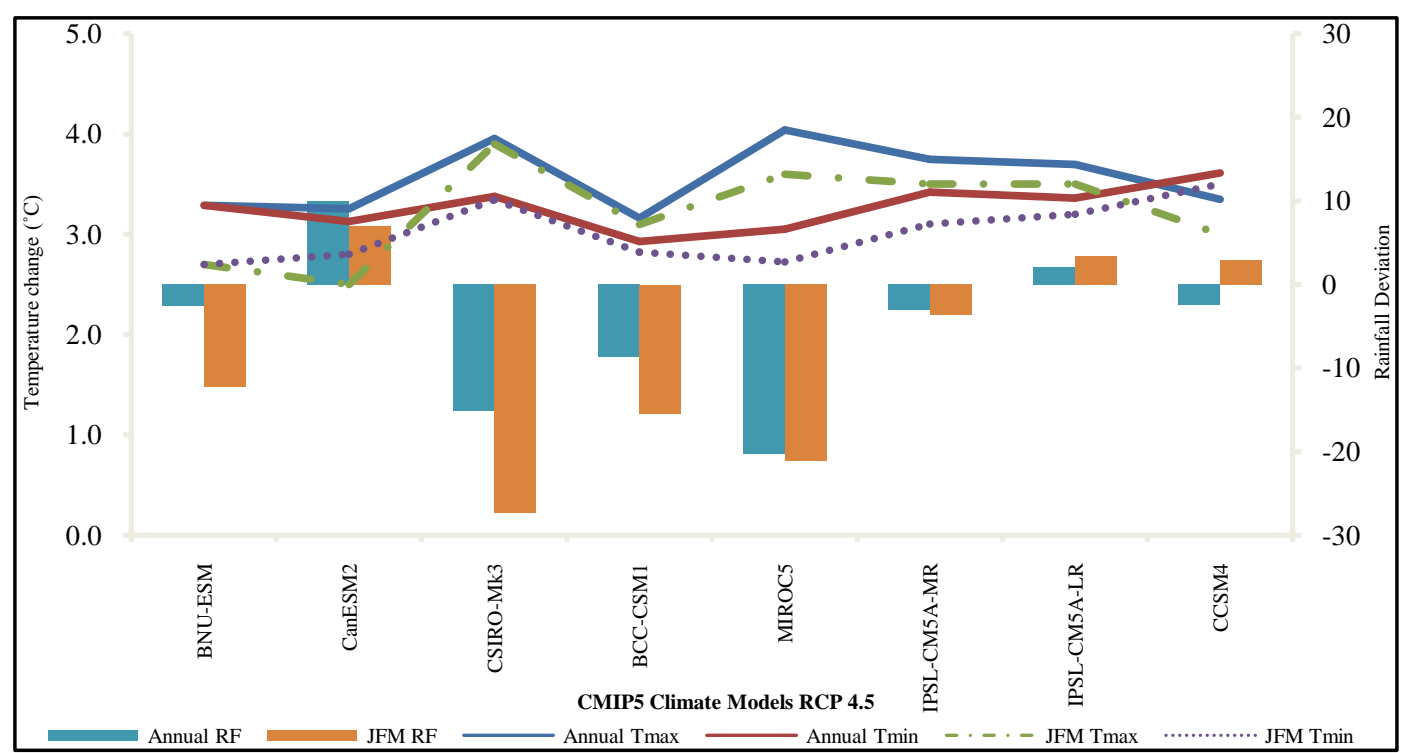

Figure 1. Projected changes in rainfall (percent deviation from historic rainfall) and temperatures (absolute change) for RCP 4.5 to midcentury for Hombolo station (RF = rainfall; JFM = January February March).
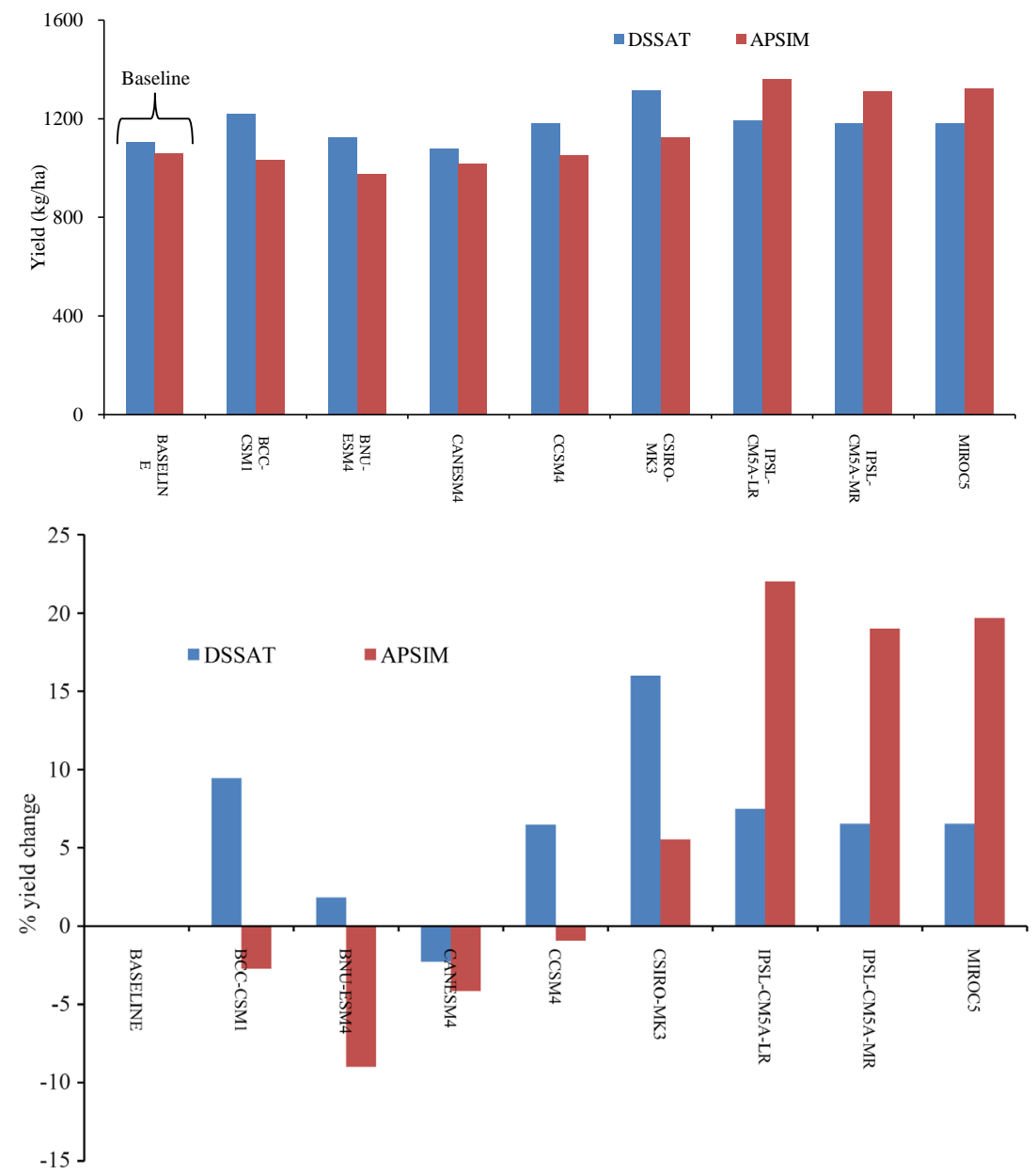

Figure 2. Sensitivity of current sorghum production system to climate change projections by 2050 . 
expected to increase, decrease or remain unchanged under different GCMs, scenarios and locations hence corroborating the intrinsic uncertainty in crop yield predictions using the current methodologies. These studies show a wide range of possible impacts of climate change on sorghum in different locations, ranging from negative to positive, highlighting the need for location-specific studies to inform decision making and policy to manage risks and vulnerability associated with impacts of climate change.

\subsection{Crop Cultivar Selection}

Choice of cultivar (short versus long duration) as adaptation options, were tested through adjustment of the genetic coefficients in DSSAT, and results of simulations are shown in Table 7. Results indicate that increasing the duration of growth of cultivar in the field give increased yields. This is the current situation with the local photoperiod sensitive cultivars which smallholder farmers continue to grow. Similarly, increasing the thermal time accumulation from grain filling period to maturity, give positive results though with lower magnitude compared to increased duration. Results reported by [37] show that the photoperiod-sensitive traditional cultivars of millet and sorghum that have been used by local farmers for centuries may be more resilient to future climate conditions than modern cultivars bred for their high yield potential. Their results corroborate those from [38] who propose the reinserting of photoperiod sensitivity back into modern sorghum cultivars in order to give farmers more flexibility in sowing dates in semi-arid environments where the onset of the rainy season is highly variable. Despite some studies showing that temperature rise will lead to sorghum yield reduction [34] and [39], future projections in temperatures by the GCMs used in the current study for central Tanzania show that the underlying conditions for yield reduction may not have been attained by the 2050s to cause appreciable yield reductions.

\section{Conclusion}

Understanding crop response towards projected changes in climate is required for formulating adaptation strategies and policy. Crop simulation models help to understand crop bio dynamism under changing climatic conditions. The calibration and evaluation of crop models has given more insight into the influence of variability in temperature and rainfall regimes on sorghum in central Tanzania. Considering future climates up to 2050s, productivity of grain sorghum will be diversely affected due to the differences in the GCMs projections in temperature and rainfall. Increase of $5 \%-23.0 \%$ in sorghum yields is projected by both crop models under four GCMs. Contrasting results also have been observed with the other GCMs. The simulation results under adjustment of crop growing duration under future projections show increase of median sorghum yields according to CERES-sorghum model. We conclude that with proper calibrations and evaluations, crop models can reasonably predict future sorghum yields in the study area and other area with similar environments. This study, quantitatively ascertains the current promotion of sorghum production as an appropriate crop to be grown in the study area, instead of the continued reliance on maize as a staple crop which is currently at high risk. Modifying management practices through the deliberate choice between improved cultivars and local landraces can be feasible options depending on GCM for enhancing the adaptive capacity of smallholder farmers in central Tanzania, to ensure increased production of the crop for enhanced food security and livelihoods.

\section{Acknowledgements}

Thanks are due to the Regional Universities Forum for Capacity Building in Agriculture (RUFORUM) for funding this study. Provision of weather data from Tanzania Meteorological Agency (TMA) is appreciated. En-

Table 7. Genetic advancement and duration of sorghum (Tegemeo) under future climate scenario.

\begin{tabular}{|c|c|c|c|c|c|}
\hline Coefficients & Ranges & Initial value & Final value & $\begin{array}{c}\text { Yield change range } \\
\text { (\%) }\end{array}$ & $\begin{array}{l}\text { Average yield change } \\
(\%)\end{array}$ \\
\hline $\begin{array}{l}\text { Thermal time grain filling } \\
\text { to maturity (P5) }\end{array}$ & $450-640$ & 580 & 640 & $2-9$ & +5 \\
\hline Relative leaf size (G1) & $3-22$ & 11 & 15 & $0.3-1.1$ & +0.7 \\
\hline Partitioning to panicle (G2) & $4.5-6.5$ & 6 & 6.5 & $7-9$ & +8 \\
\hline Cultivar duration (days) & $90-150$ & 110 & 130 & $0-100$ & +15 \\
\hline
\end{tabular}


hancing Climate Change Adaptation in Agriculture and Water Resources in the Greater Horn of Africa (ECAW) and Agricultural Model Intercomparison and Improvement Project (AgMIP) supported the crop model training with APSIM and DSSAT.

\section{References}

[1] Rohrbach, D.D. (2004) Improving the Commercial Viability of Sorghum and Pearl Millet in Africa. Series Report.

[2] Monyo, E.S., Ngereza, J., Mgonja, M.A., Rohrbach, D.D., Saadan, H.M. and Ngowi, P. (2004) Adoption of Improved Sorghum and Pearl Millet Technologies in Tanzania. International Crops Research Institute for the Semi Arid Tropics, Bulawayo, 28 p.

[3] Berg, A., de Noblet-Ducoudre, N., Sultan, B., Lengaigne, M. and Guimberteau, M. (2013), Projections of Climate Change Impacts on Potential C4 Crop Productivity over Tropical Regions. Agricultural and Forest Meteorology, 170, 89-102. http://dx.doi.org/10.1016/j.agrformet.2011.12.003

[4] Cooper, P.J.M., Dimes, J., Rao, K.P.C., Shapiro, B., Shiferawa, B. and Twomlow, S. (2008) Coping Better with Current Climatic Variability in the Rain-Fed Farming Systems of Sub-Saharan Africa: An Essential First Step in Adapting to Future Climate Change? Agriculture, Ecosystems and Environment, 126, 24-35. http://dx.doi.org/10.1016/j.agee.2008.01.007.

[5] White, J.W., Hoogenboom, G., Kimball, B.A. and Wall, G.W. (2011) Methodologies for Simulating Impacts of Climate Change on Crop Production. Field Crop Research, 124, 357-368.

http://dx.doi.org/10.1016/j.fcr.2011.07.001.

[6] Ramirez-Villegas, J., Challinor, A.J., Thornton. K.P. and Jarvis, A. (2013) Implications of Regional Improvement in Global Climate Models for Agricultural Impact Research. Environmental Research Letters, 8, Article ID: 024018. http://dx.doi.org/10.1088/1748-9326/8/2/024018.

[7] McCown, R.L., Hammer, G.L., Hargreaves, J.N.G., Holzworth, D.P. and Freebairn, D.M. (1996) APSIM: A Novel Software System for Model Development, Model Testing, and Simulation in Agricultural Systems Research. Agricultural Systems, 50, 255-271. http://dx.doi.org/10.1016/0308-521X(94)00055-V

[8] Keating, B.A., Carberry, P.S., Hammer, G.L., Probert, M.E., Robertson, M.J., Holzworth, D., Huth, N.I., Hargreaves, J.N.G., Meinke, H., Hochman, Z., McLean, G., Verburg, K., Snow, V., Dimes, J.P., Silburn, M., Wang, E., Brown, S., Bristow, K.L., Asseng, S., Chapman, S., McCown, R.L., Freebairn, D.M. and Smith, C.J. (2003) An Overview of APSIM, a Model Designed for Farming Systems Simulation. European Journal of Agronomy, 18, 267-288. http://dx.doi.org/10.1016/S1161-0301(02)00108-9

[9] Jones, J.W., Hoogenboom, G., Porter, C.H., Boote, K.J., Batchelor, W.D. and Hunt, L.A. (2003) DSSAT Cropping System Model. European Journal of Agronomy, 18, 235-265. http://dx.doi.org/10.1016/S1161-0301(02)00107-7.

[10] Hoogenboom, G., Jones, J.W., Wilkens, P.W., Porter, C.H., Boote, K.J. and Hunt, L.A. (2010) Decision Support System for Agrotechnology Transfer (DSSAT) Version 4.5. University Of Hawaii, Honolulu.

[11] Wang, M., Li, Y., Ye, W., Bornman, J.F. and Yan, X. (2011) Effects of Climate Change on Maize Production and Potential Adaptation Measures: A Case Study in Jilin Province China. Climate Research, 46, 223-242. http://dx.doi.org/10.3354/cr00986

[12] Dimes, J., Cooper, P. and Rao, K.P.C. (2008) Climate Change Impact on Crop Productivity in the Semi-Arid Tropics of Zimbabwe in the 21st Century. Proceedings of the Workshop on Increasing the Productivity and Sustainability of Rain-Fed Cropping Systems of Poor Smallholder Farmers, Tamale, 22-25 September 2008, 189-198.

[13] Cooper, P., Rao, K.P.C., Singh, P., Dimes, J., Traore, P.S., Rao, K., Dixit, P. and Twomlow, S.J. (2009) Farming with Current and Future Climate Risk: Advancing a "Hypothesis of Hope” for Rainfed Agriculture in the Semi-Arid Tropics. Journal of SAT Agricultural Research, 7, 1-19.

[14] Moore, N., Alagarswamy, G., Pijanowski, B., Thornton, P., Lofgren, B., Olson, J., Andresen, J., Yanda, P. and Qi, J. (2012) East African Food Security as Influenced by Future Climate Change and Land Use Change at Local to Regional Scales. Climatic Change, 110, 823-844. http://dx.doi.org/10.1007/s10584-011-0116-7

[15] URT (2007) United Republic of Tanzania. National Adaptation Programme of Action (NAPA). Division of Environment, Vice President's Office, Dar es Salaam.

[16] Mwandosya, M.J., Nyenzi, B.S. and Luhanga, M.L. (1998) The Assessment of Vulnerability and Adaptation to Climate Change Impacts in Tanzania. The Centre for Energy, Environment, Science and Technology, CEEST, Dar es Salaam.

[17] International Food Policy Research Institute (IFPRI) (2009) Climate Change Impact on Agriculture and Costs of Adaptations. Food Policy Report, Washington DC.

[18] Craufurd, P.Q., Vincent, V., Vara Prasad, P.V., Krishna Jagadish, S.V. and Zaman Allah, M. (2011) Crop Science Ex- 
periments Designed to Inform Crop Modeling. Agricultural and Forest Meteorology, 170, 8-18. http://dx.doi.org/10.1016/j.agrformet.2011.09.003

[19] MAFSC (2012) Tanzania Variety Catalogue. Ministry of Agriculture, Food Security and Cooperatives. http://www.kilimo.go.tz/publications/publications.htm

[20] Alargarswamy, G. and Ritchie, J.T. (1991) Phasic Development in CERES-Sorghum Model. In: Hodges, T., Ed., Predicting Crop Phenology, CRC Press, Boca Raton, 143-152.

[21] Jones, C.A. and Kiniry, J. (1986) CERES-Maize: A Simulation Model of Maize Growth and Development. Texas A \& M University Press, College Station, TX.

[22] Hoogenboom, G., Jones, J.W., Traore, P.C.S. and Boote, K.J. (2012) Experiments and Data for Model Evaluation and Application. In: Kihara, J., Fatondji, D., Jones, J.W., Hoogenboom, G., Tabo, R. and Bationo, A., Eds., Improving Soil Fertility Recommendations in Africa Using the Decision Support System for Agrotechnology Transfer (DSSAT), Springer Science + Business Media, Dordrecht, 9-18.

[23] Hatibu, N., Mahoo, H.F., Senkondo, E.M., Simalenga, T.E., Kayombo, B., Ussiri, D.A.N. and Mwaseba, D. (1993) Strategies for Soil-Water Management for Dryland Crop Production in Semi-Arid Tanzania. Proceedings of Tanzania Society of Agricultural Engineers, 6, 83-97.

[24] Wallach, D. (2006) Evaluating Crop Models. In: Wallach, D., Makowski, D. and Jones, J.W., Eds., Working with Dynamic Crop Models Evaluation, Analysis, Parameterization, and Applications, Elsevier, Amsterdam, 11-54.

[25] Willmott, C.J., Akleson, G.S., Davis, R.E., Feddema, J.J., Klink, K.M., Legates, D.R., Odonnell, J. and Rowe, C.M. (1985) Statistics for the Evaluation and Comparison of Models. Journal of Geophysical Research, 90, 8995-9005 http://dx.doi.org/10.1029/JC090iC05p08995.

[26] Mote, P.W. and Salathé, E.P. (2009) Future Climate in the Pacific Northwest. Chapter 1 in the Washington Climate Change Impacts Assessment: Evaluating Washington's Future in a Changing Climate, Climate Impacts Group, University of Washington, Seattle, Washington.

[27] Thornton, P.K., Jones, P.G., Alagarswamy, A. and Andresen, J. (2009) Spatial Variation of Crop Yield Responses to Climate Change in East Africa. Global Environmental Change, 19, 54-65 http://dx.doi.org/10.1016/j.gloenvcha.2008.08.005.

[28] Staggenborg, S.A. and Vanderlip, R.L. (2005) Crop Simulation Models Can Be Used as Dry-Land Cropping Systems Research Tools. Agronomy Journal, 97, 378-384. http://dx.doi.org/10.2134/agronj2005.0378

[29] Varshneya, M.C., Thorat, B.P., Narkhede, B.N., Jadhava, A.S., Naidu, T.R.V. and Karande, B.I. (1998) Performance of CERES-Sorghum Model for Rainfed Sorghum Grown on Conserved Soil Moisture. Journal of Maharashtra Agricultural Universities, 23, 55-57.

[30] Suchit, K.R., Gupta, B.R.D. and Mishra, R. (2004) Sensitivity Analysis of CERES-Sorghum Model for Forage Sorghum. Journal of Agrometeorology, 6, 205-214.

[31] Meehl, G.A., et al. (2007) Global Climate Projections. In: Climate Change 2007: The Physical Science Basis. Contribution of Working Group I to the Fourth Assessment Report of the Intergovernmental Panel on Climate Change, Cambridge University Press, Cambridge.

[32] IPCC (2007) Climate Change: Impacts, Adaptation and Vulnerability. In: Parry, M.L., Canziani, O.F., Palutikof, J.P., van der Linden, P.J. and Hanson, C.E., Eds., Contribution of Working Group II to the 4th Assessment Report of the Intergovernmental Panel on Climate Change, Cambridge University Press, Cambridge, 976.

[33] Mishra, A., Hansen, J.W., Dingkuhn, M., Baron, C., Traore, S.D., Ndiaye, O. and Ward, M.N. (2008) Sorghum Yield Prediction from Seasonal Rainfall Forecasts in Burkina Faso. Agricultural and Forest Meteorology, 148, 1798-1814. http://dx.doi.org/10.1016/j.agrformet.2008.06.007

[34] Prasad, P.V.V., Boote, K.J. and Allen, L.H. (2006) Adverse High Temperature Effects on Pollen Viability, Seed Set, Seed Yield and Harvest Index of Grain-Sorghum [Sorghum bicolor (L.) Moench] Are More Severe at Elevated Carbon Dioxide Due to Higher Tissue Temperature. Agricultural and Forest Meteorology, 139, 237-251. http://dx.doi.org/10.1016/j.agrformet.2006.07.003.

[35] Tingem, M., Rivington, M. and Bellocchi, G. (2009) Adaptation Assessment for Crop Production in Response to Climate Change in Cameroon. Agronomy for Sustainable Development, 29, 247-256. http://dx.doi.org/10.1051/agro:2008053

[36] Srivastava, A., Naresh Kumar, S. and Aggarwal, P.K. (2010) Assessment on Vulnerability of Sorghum to Climate Change in India. Agriculture, Ecosystems and Environment, 138, 160-169. http://dx.doi.org/10.1016/j.agee.2010.04.012

[37] Sultan, B., Roudier, P., Quirion, P., Alhassane, A., Muller, B., Dingkuhn, M., Ciais, P., Guimberteau, M., Traore, S. and Baron, C. (2013) Assessing Climate Change Impacts on Sorghum and Millet Yields in the Sudanian and Sahelian 
Savannas of West Africa. Environmental Research Letters, 8, Article ID: 014040. http://dx.doi.org/10.1088/1748-9326/8/1/014040

[38] Dingkuhn, M., Singh, B.B., Clerget, B., Chantereau, J. and Sultan, B. (2006) Past, Present and Future Criteria to Breed Crops for Water-Limited Environments in West Africa. Agricultural Water Management, 80, 241-261. http://dx.doi.org/10.1016/j.agwat.2005.07.016

[39] Prasad, P.V.V. and Staggenborg, S.A. (2009) Growth and Production of Sorghum and Millets. In: Soils, Plant Growth and Crop Production - Volume II, Encyclopedia of Life Support Systems, Eolss Publishers, Oxford. 
Scientific Research Publishing (SCIRP) is one of the largest Open Access journal publishers. It is currently publishing more than 200 open access, online, peer-reviewed journals covering a wide range of academic disciplines. SCIRP serves the worldwide academic communities and contributes to the progress and application of science with its publication.

Other selected journals from SCIRP are listed as below. Submit your manuscript to us via either submit@scirp.org or Online Submission Portal.
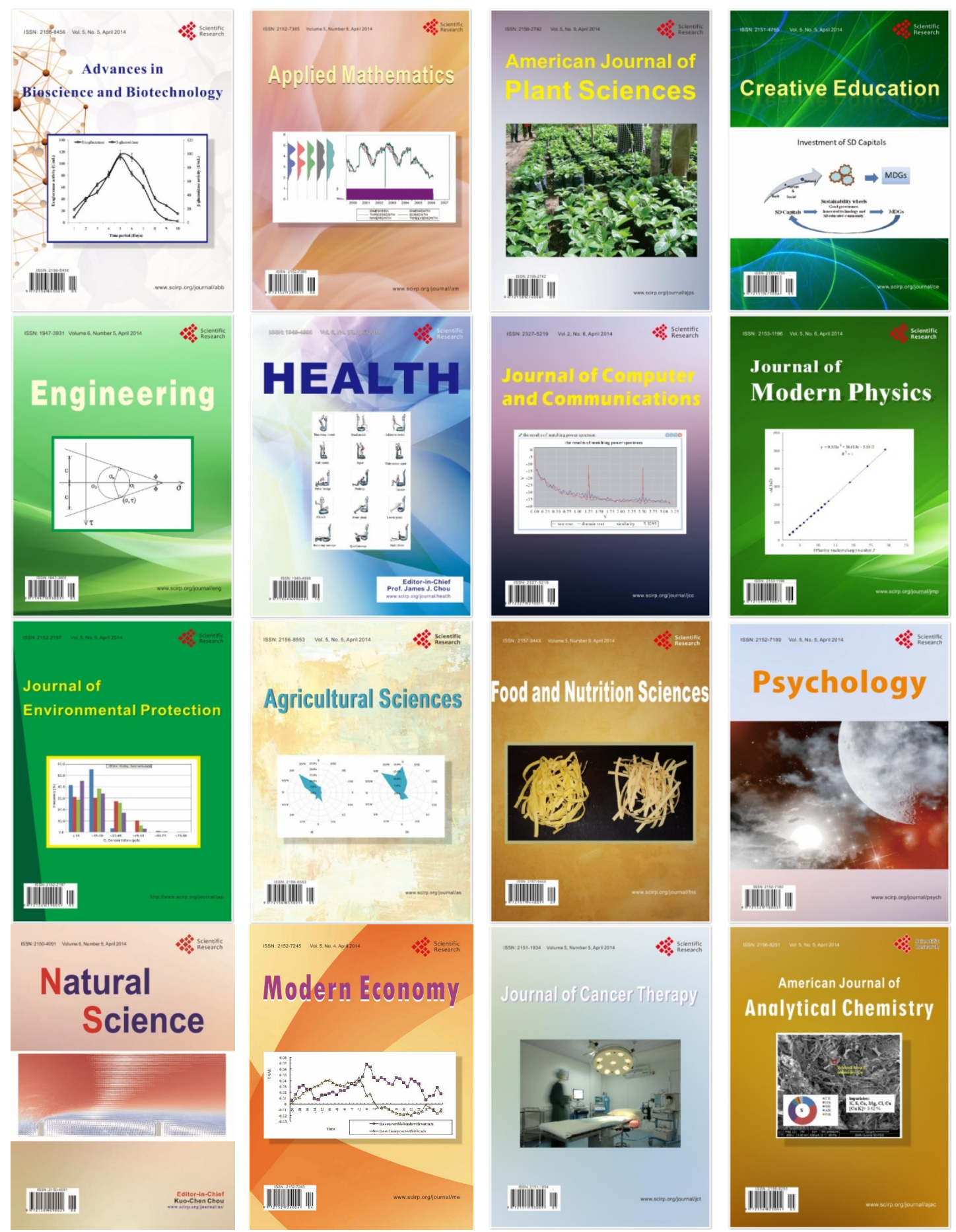